\title{
THE ROLE OF ULTRASONOGRAPHY IN THE DIAGNOSIS OF FUNCTIONAL DYSPEPSIA
}

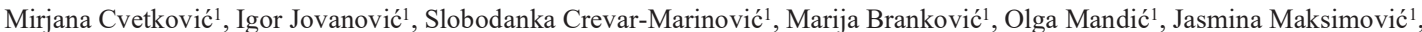
Nataša Zdravković ${ }^{2,3}$, Stefan Simović ${ }^{2,4}$ and Nataša Stanisavljević ${ }^{1}$ ${ }^{I}$ Clinical-Hospital Center "Bežanijska Kosa”, Belgrade, Serbia

${ }^{2}$ Department of Internal Medicine, Faculty of Medical Sciences, University of Kragujevac, Kragujevac, Serbia ${ }^{3}$ Clinical Centre Kragujevac, Clinic of Gastroenterohepatology, Kragujevac, Serbia

${ }^{4}$ Clinical Centre Kragujevac, Clinic of Cardiology, Kragujevac, Serbia

\author{
ULOGA ULTRASONOGRAFIJE U DIJAGNOZI \\ FUNKCIONALNE DISPEPSIJE

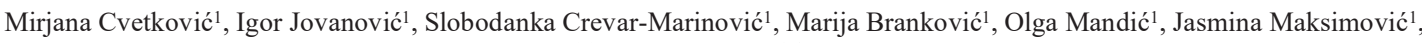 \\ Nataša Zdravković ${ }^{2,3}$, Stefan Simović ${ }^{2,4}$ i Natasa Stanisavljević ${ }^{1}$ \\ ${ }^{1}$ Kliničko-bolnički centar, Bežanijska Kosa, Beograd, Srbija \\ ${ }^{2}$ Katedra za internu medicine, Fakultet medicinskih nauka, Univerzitet u Kragujevcu, Kragujevac, Srbija \\ ${ }^{3}$ Klinički centar Kragujevac, Klinika za gastroenterohepatologiju, Kragujevac, Srbija \\ ${ }^{4}$ Klinički centar Kragujevac, Klinika za kardiologiju, Kragujevac, Srbija
}

\begin{abstract}
Background: Functional dyspepsia (FD) is a syndrome mostly diagnosed by subjective patients' symptoms after excluding organic, systemic and metabolic diseases. Aim: The goal of this study is to evaluate gastric emptying in patients with functional dyspepsia, by measuring the antral area (cm2) after the intake of a test meal using ultrasonography as an objective and widely applicable method. Material and Methods: This study included 30 patients (mean age of $46.53 \pm 9.73$ years) with symptoms of FD according to the ROMA IV criteria and 30 healthy individuals (mean age of $42.87 \pm 4.42$ years). A $5 \mathrm{MHz}$ ultrasound probe was used to measure the stomach antral area at 6 different time points: in the fasting state, following the meal intake at 5, 30, 60, 90 and 120 min postprandially. Results: The antral area was statistically significantly larger after a 30-minute postprandial period in patients with FD comparing to healthy controls $(p<0.05)$. There was a statistically significant difference in the rate of gastric emptying at 120 minutes in patients with functional dyspepsia, compared to healthy subjects $(p<0.01)$. Patients with postprandial distress syndrome had the average value of gastric emptying 48.25 compared to 56.09 in patients with epigastric pain syndrome $(p<0.05)$. The slowest emptying was observed in patients with nausea and postprandial fullness ( $p<0.05)$. Conclusion: Functional dyspepsia is associated with delayed gastric emptying. Using ultrasonography to measure the antral area helps us to assess gastric emptying and therefore to assess patients with functional dyspepsia. The antral area was significantly larger in patients with functional dyspepsia compared to healthy subjects after the test meal, suggesting slower gastric emptying in the dyspeptic patients. Since the diagnosis of functional dyspepsia is based mostly on diverse patients' symptoms, using ultrasonography to measure the antral area helps us to objectively assess this problem.

Keywords: functional dyspepsia, ultrasonography.
\end{abstract}

\section{SAŽETAK}

Uvod: Funkcionalna dispepsija (FD) je sindrom koji se uglavnom dijagnostikuje na osnovu subjektivnih simptoma pacijenata, nakon isključivanja organskih, sistemskih $i$ metaboličkih bolesti. Ciljevi: Cilj studije je procena pražnjenja želuca kod pacijenata sa funkcionalnom dispepsijom, merenjem antralne površine $\left(\mathrm{cm}^{2}\right)$ nakon uzimanja probnog obroka, koristeći ultrasonografiju kao objektivnu i široko primenljivu metodu. Materijal i metode: Studija je obuhvatila 30 pacijenata (prosečna starost 46,53 \pm 9,73 godina) sa simptomima FD prema kriterijumima ROMA IV I 30 zdravih ispitanika (prosečna starost 42,87 $\pm 4,42$ godina). Ultrazvučna sonda od $5 \mathrm{MHz}$ je korišćena za merenje antralnog područja želuca u 6 različitih vremenskih tačaka: u stanju gladovanja, nakon uzimanja obroka na 5, 30, 60, 90 I 120 minut nakon obroka. Rezultati: Antralno područje je statistički značajno veće nakon 30 minuta. postprandialnog perioda kod pacijenata sa FD u poređenju sa zdravim kontrolama ( $p$ <0,05). Postojala je statistički značajna razlika u brzini pražnjenja želuca u 120-tom minutu kod pacijenata sa funkcionalnom dispepsijom, u poređenju sa zdravim ispitanicima $(p<0,01)$. Pacijenti sa postprandialnim distres sindromom imali su prosečnu vrednost pražnjenja želuca 48,25 u poređenju sa 56,09 kod pacijenata sa sindromom epigastričnog bola $(p<0,05)$. Najsporije pražnjenje primećeno je kod pacijenata sa mučninom $i$ punoćom nakon obroka $(p<0,05)$. Zaključak: Funkcionalna dispepsija povezana je sa odloženim pražnjenjem želuca. Korišćenje ultrasonografije za merenje antralnog područja pomaže nam da procenimo pražnjenje želuca $i$ samim tim $i$ pacijente sa funkcionalnom dispepsijom. Antralno područje je bilo značajno veće kod pacijenata sa funkcionalnom dispepsijom u poređenju sa zdravim ispitanicima nakon probnog obroka, što ukazuje na sporije pražnjenje želuca kod pacijenata sa dispepsijom. Budući da se dijagnoza funkcionalne dispepsije zasniva uglavnom na različitim simptomima pacijenata, korišćenje ultrasonografije za merenje antralnog područja pomaže nam da objektivno procenimo ovaj problem.

Ključne reči: funkcionalna dispepsija, ultrasonografija. 
ABBREVIATIONS

FD - Functional dyspepsia

PDS - Postprandial Distress Syndrome

EPS - Epigastric Pain Syndrome
MRI - Magnetic resonance imaging

GI - Gastrointestinal

\section{INTRODUCTION}

Functional dyspepsia (FD) is a syndrome originating from the gastroduodenal segment of the digestive tube and it is the most common functional disorder of the digestive tube. It is estimated that $40 \%$ of adults have dyspeptic symptoms at least once a year, most often diagnosed in the fifth decade of life and equally present in both sexes.

According to the Rome IV criteria, functional dyspepsia is defined as the presence of postprandial fullness, early satiety, epigastric pain and burningthat are severe enough to interfere with the usual activities. The diagnostic criteria imply the presence of one or more of these symptoms during 3 days per week in the last 3 months, with the onset, at least, 6 months ago. The upper gastrointestinal symptoms such as nausea, belching, or abdominal bloating can also occur. According to the burden symptoms, patients can be classified into two subgroups of functional dyspepsia $(1,2)$ :

- $\quad$ Postprandial Distress Syndrome (PDS)

- $\quad$ Epigastric Pain Syndrome (EPS)

The pathophysiology of FD is complex. The key mechanism for the onset of functional dyspepsia is impaired gastrointestinal motility and sensitivity. Slow gastric emptying, impaired gastric accommodation and visceral hypersensitivity are most commonly associated with functional dyspepsia. These three mechanisms are related and difficult to examine each. The symptoms induced by gastric distension are not region-specific. The measurement of gastric emptying is most accessible and is a good indicator of gastric motility disorders (3-6).

The percentage of dyspeptic patients with delayed gastric emptying ranges from $20 \%-50 \%$. However, most of the studies were performed in small groups of patients and small control groups. In the largest studies, gastric emptying of solids was delayed in about $30 \%$ of patients with functional dyspepsia $(3,7)$. The measurement of gastric emptying may be useful in understanding the severity of dyspeptic symptoms. The gold standard for measuring gastric emptying is scintigraphy. Other reliable methods include the breath test, magnetic resonance imaging (MRI), gastric aspiration techniques, epigastric impedance measurements, electrogastrography and other methods. Ultrasound of the stomach was initially performed to detect and investigate organic diseases. Ultrasound can be used to evaluate the antral contractility, gastric emptying, transpyloric flow, gastric configuration, intragastric distribution of meals, gastric accommodation and strain of the gastric wall. Several studies have demonstrated a good correlation between scintigraphy and ultrasonography in the evaluation of gastric function $(6,7,8)$. The antrum is the most accessible part of the stomach for the ultrasound measurement. It is often used for assessing gastric emptying. Measuring the area of the antrum and change of its size in time is associated with the patient's perception of fullness $(9,10)$. Ultrasound is a non-invasive, safe, reproducible, widely available method and does not require expensive equipment. Ultrasonography does not change the physiology of the gastrointestinal tract and is widely available in the outpatient settings (11). We used ultrasonography to evaluate gastric motility since this method is available in most institutions and is easy to apply and can be recommended in the diagnosis of FD.

It is difficult to correctly diagnose functional dyspepsia according to the subjective assessment of the patient, considering the variety of symptoms. The aim of this paper is to show how ultrasonography can disclose organic disease and functional behavior of the GI tract. The significance of this paper is to show that using ultrasound measurement of the antral surface could help in the functional dyspepsia diagnosis in an objective way.

\section{MATERIALS AND METHODS}

This study included a total of 60 participants: the group of patients with symptoms of FD according to the ROMA IV criteria (21 patients with PDS (the average age 46.5) and 9 patients with EPS (the average age 46.5)) and 30 (the average age 42.7) healthy individuals without any symptoms. The group of participants was recruited at the Medical Center "Bezanijska kosa" from January 2019 to September 2019.

The inclusion criteria for the study were patients with FD according to the ROMA IV criteria. The exclusion criteria were pathological laboratory findings (liver or kidney failure), all patients who were Helicobacter pylori-positive, patients who were treated for Helicobacter. pylori infection in the previous six months, patients with a gallbladder stone, diabetics as well as patients with other metabolic disorders, organic or systemic diseases and all patients who took the therapy that affects the motility of the digestive tract. Patients should not take the medications such as metoclopramide, erythromycin and anticholinergic drugs for 48 hours before the testing. All patients were asked about the dyspeptic symptoms before the testing. 
All procedures conducted in patients were in accordance with the ethical standards of the Institutional Research Committee and with the 1964 Helsinki Declaration and its later amendments or comparable ethical standards. Informed consent was obtained from all individual participants included in the study.

A $5 \mathrm{MHz}$ ultrasound probe (Hitachi EUB-5500) was used to measure the area of the antrum of the stomach. The antral area was visualized in the sagittal plane scan between the left lobe of the liver, pancreas, aorta or vein cava inferior and superior mesenteric vein. The measurements were performed in the supine position, in the right decubitus. The outer profile of the antrum was measured using the built-in caliper and calculation program of the ultrasound apparatus. The minimal amount of force was applied during each reading to prevent compression of the antrum $(10,11)$. To ensure the accuracy of the results, the measurements were taken twice and then averaged.

\section{RESULTS}

According to the ROMA III classification criteria for functional dyspepsia, there were 21 patients with postprandial distress syndrome (70\%) and 9 with epigastric pain $(30 \%)$ in the study group. The patients reported the following symptoms: epigastric pain in $3(10 \%)$, bloating in $5(16.7 \%)$, postprandial fulness in $7(23.3 \%)$, nausea in 5 (16.7\%), belching in $10(33.3 \%)$ patients. The most intensive symptoms were reported by $8(26.7 \%)$ patients in the first five minutes, $16(53.3 \%)$ patients from 6-30 minutes and 6 (20\%) patients from 31-60 minutes.
Before starting the test, each participant fasted for eight hours prior to the study. The antral area was measured at 6 different time points: in the fasting state, following the meal intake at 5, 30, 60, 90 and 120 minutes postprandially. Each participant took a $150 \mathrm{Kcal}$ meal $(17 \mathrm{~g}$ protein, $15 \mathrm{~g}$ fat and $27 \mathrm{~g}$ carbohydrate) with $200 \mathrm{ml}$ of water. At each time point, the participants were asked to record the severity of each dyspeptic symptom (epigastric pain, burning in the stomach, postprandial fullness, early satiety, bloating, nausea, vomiting and belching).

\section{Statistical analysis}

Numerical variables were expressed as the mean \pm SD for normal distribution or median for non-normal distribution, or with frequency and percentage for the categorical data. The comparison of groups was performed using Student's t-test and ANOVA for normally distributed data. $\chi 2$ analysis was used to test the relation between non-continuous variables. Pvalue below 0.05 was considered significant. The whole analysis was performed with the SPSS statistical analysis software, Version 20.0 (SPSS, Chicago, Illinois, USA).

There was no significant statistical difference between the antral area surface in patients with functional dyspepsia (3.44 $\pm 1.50 ; 14.40 \pm 5.15)$ and healthy controls $(3.26 \pm 0.64$ $12.47 \pm 1.96)$ during fasting, and at 5 minutes after the test meal ( $p>0.05$, respectively). The antral area was statistically significantly larger over a 30 -minute postprandial period in patients with FD comparing to healthy controls $(12.03 \pm 4.28$ vs $9.54 \pm 2.04)(p<0.05)$. Measurements of the antral surface in the study and control group through every time point were depicted in Table 1.

Table 1. Measurements of the antral surface area in the study population.

\begin{tabular}{|l|l|l|c|c|c|}
\hline \multicolumn{1}{|c|}{$\begin{array}{c}\text { Antral area } \\
\text { surface }\end{array}$} & \multicolumn{1}{c|}{ group } & $\mathrm{N}$ & mean & $\begin{array}{c}\text { Standard } \\
\text { deviation }\end{array}$ & $\mathrm{p}$ \\
\hline \multirow{2}{*}{0. minutes } & study & 30 & 3.44 & 1.50 & $>0.05$ \\
\cline { 2 - 6 } & control & 30 & 3.26 & 0.64 & \\
\hline \multirow{2}{*}{5. minutes } & study & 30 & 14.40 & 5.15 & $>0.05$ \\
\cline { 2 - 6 } & control & 30 & 12.47 & 1.96 & \\
\hline \multirow{2}{*}{ 30.minutes } & study & 30 & 12.03 & 4.28 & $<0.05$ \\
\cline { 2 - 6 } & control & 30 & 9.54 & 2.04 & $<0.05$ \\
\hline \multirow{2}{*}{ 60.minutes } & study & 30 & 10.38 & 4.16 & $<0.05$ \\
\cline { 2 - 6 } & control & 30 & 8.01 & 1.72 & $<0.05$ \\
\hline \multirow{2}{*}{ 120.minutes } & study & 30 & 8.80 & 3.60 & \\
\cline { 2 - 6 } & control & 30 & 5.63 & 3.04 & 0.66 \\
\hline
\end{tabular}


There was a statistically significant difference in the rate of gastric emptying at 120 minutes in patients with functional dyspepsia (60.60 \pm 9.95$)$, compared to healthy subjects (69.62 \pm 6.66$),(p<0.01)$. There was a significant difference comparing gastric emptying between the subgroups of patients with FD. Patients with postprandial distress syndrome had the average value of gastric emptying 48.25 compared to 56.09 in patients with epigastric pain syndrome $(\mathrm{p}<0.05)$.
Also, there was a significant difference between the study and control group when measuring 50\% gastric emptying $(\mathrm{p}<0.5)$. There was significantly faster gastric emptying in healthy subjects. All healthy subjects $(100 \%)$ had gastric emptiness over $50 \%$ at 120 minutes, while $53.3 \%$ of dyspeptic patients had emptiness less than $50 \%$ at 120 minutes, $(p<0.01)$, (Table 2).

Table 2. Measurement of gastric emptying in the study population.

\begin{tabular}{|c|c|c|c|c|c|}
\hline & \multirow{2}{*}{\multicolumn{2}{|c|}{$\mathrm{p} 50$}} & \multirow{3}{*}{ Total } & \multirow{3}{*}{$\mathrm{p}$} \\
\hline & & & & & \\
\hline Group & & $<=50 \%$ & $>50 \%$ & & \\
\hline \multirow{3}{*}{ study } & Number & 16 & 14 & 30 & \\
\hline & $\%$ & $53.3 \%$ & $46.7 \%$ & $100.0 \%$ & \multirow{3}{*}{$<0.01$} \\
\hline & $\% \mathrm{p} 50$ & $100.0 \%$ & $31.8 \%$ & $50.0 \%$ & \\
\hline \multirow{3}{*}{ control } & Number & 0 & 30 & 30 & \\
\hline & $\%$ & $0.0 \%$ & $100.0 \%$ & $100.0 \%$ & \\
\hline & $\% \mathrm{p} 50$ & $0.0 \%$ & $68.2 \%$ & $50.0 \%$ & \\
\hline \multirow{3}{*}{ All } & Number & 16 & 44 & 60 & \\
\hline & $\%$ group & $26.7 \%$ & $73.3 \%$ & $100.0 \%$ & \\
\hline & $\%$ p50 & $100.0 \%$ & $100.0 \%$ & $100.0 \%$ & \\
\hline
\end{tabular}

ANOVA test showed significant differences in the mean values of the rate of gastric emptying in the 120th minute compared to the most intensive symptoms during the test.
The slowest emptying was observed in patients with nausea and postprandial fullness $(\mathrm{p}<0.05)$, (Table 3 and Figure 1$)$.

Table 3. GER by symptoms.

\begin{tabular}{|l|c|c|c|c|c|}
\hline \multicolumn{1}{|c|}{ GER } & N & Mean & SD & Minimum & Maximum \\
\hline epigastric pain & 3 & 62.63 & 13.66 & 49.30 & 76.60 \\
\hline bloating & 5 & 51.06 & 9.67 & 35.84 & 62.38 \\
\hline Postprandial fullness & 7 & 47.57 & 7.85 & 35.41 & 56.35 \\
\hline nausea & 5 & 42.33 & 10.96 & 27.35 & 55.97 \\
\hline belching & 10 & 53.01 & 6.42 & 43.06 & 60.70 \\
\hline Total & 30 & 50.60 & 9.95 & 27.35 & 76.60 \\
\hline
\end{tabular}

Figure 1. Mean GER by the most intensive symptoms.

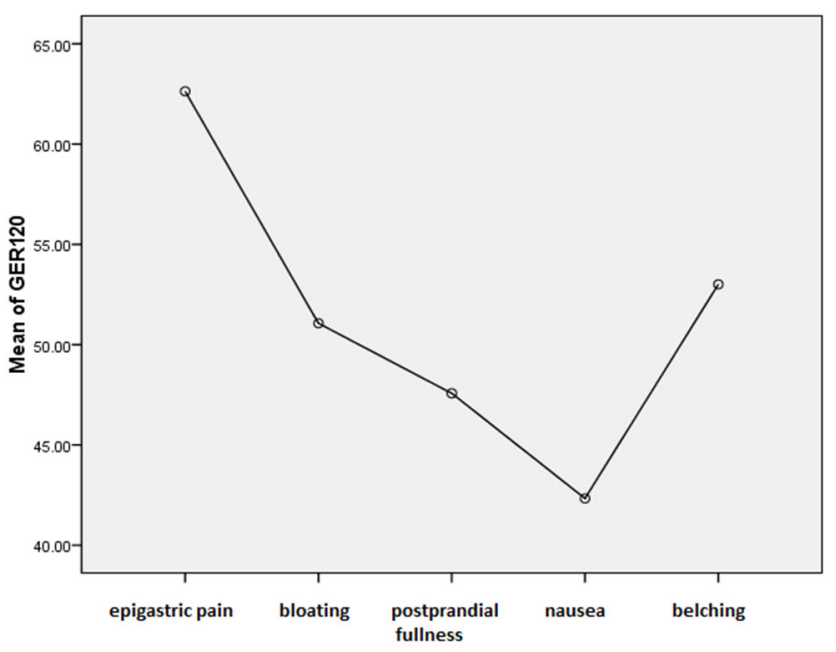




\section{DISCUSSION}

Our study showed that ultrasonography, as an easy, effective and non-invasive modality, could be used in clinical practice to evaluate gastric emptying in both, healthy participants and those with gastrointestinal disorders, such as FD. As the antrum is the most accessible part of the stomach, we used the ultrasonography method to determine the size of the antrum after the test meal as a measure of gastric emptying.

Dyspepsia is a persistent or recurrent feeling of discomfort or pain in the upper abdomen. The pathophysiology of FD is complex. Gastrointestinal motility disorders (slowed gastric emptying and impaired gastric accommodation) are the most common cause of functional dyspepsia. The measurement of gastric emptying may be useful in understanding the severity of dyspeptic symptoms. Numerous studies have examined the association between delayed gastric emptying and dyspepsia. Depending on the type of study, the percentage of dyspeptic patients with delayed gastric emptying ranges from $20 \%-50 \%$. In a meta-analysis of 17 studies involving 868 patients and 397 healthy, significantly slower gastric emptying was observed in $40 \%$ of patients with functional dyspepsia (3). In some studies, it has been found that slowed gastric emptying is associated with a feeling of postprandial fullness, nausea and vomiting $(12,13)$. In an early study by HauskennT.et others, it was shown that the mean antral area was wider in patients with functional dyspepsia than in healthy controls (14).

In this study, the ultrasound examination of the antrum function (change in the size of the antrum per unit time) was performed, which is otherwise often used in examinations of the degree of gastric emptying. Although scintigraphy is the gold standard in the examination of gastric emptying, the ultrasound technique has advantages, because it is non-invasive, reproducible and does not require expensive equipment. The worldwide studies of the validity of ultrasound monitoring of gastric function in relation to scintigraphy have been performed and it has been found that there is a good correlation between these two methods. There is also no significant difference in the position the patient assumes during the testing, whether lying down or sitting, there is also agreement in the findings between different examiners when measurements are performed on the same patients under the same conditions $(8,17,18)$.

In this study, it was shown that the average antrum area observed per unit time in the FD group and the control group did not differ in fasting and 5 minutes after the intake of the test meal. From 30 minutes up to 120 minutes, the average area of the antrum in the control group was smaller. The level of gastric emptying at 120 minutes after the test meal, was less in patients with functional dyspepsia than in healthy subjects. Observed at 120 minutes, 16 of 30 patients $(53.3 \%)$ had the level of gastric emptying less than $50 \%$ in the FD group , while all healthy subjects had the level of gastric emptying over $50 \%$. There was a statistically significant difference in the distribution of subjects with functional dyspepsia and control groups concerning gastric emptying of $50 \%$, after the test meal.

The obtained data are consistent with the previous publications, where it has been found that the percentage of patients with functional dyspepsia and slowed gastric emptying depends on the study, ie. the test conditions varied in the range of $20 \%-50 \%(3,7)$.

In this study, slower gastric emptying was found in a patient with postprandial distress syndrome, compared to subjects with epigastric pain syndrome. In the literature, delayed gastric emptying has been associated with postprandial distress syndrome $(19,20)$.

The complaints reported by patients as the most intense ones during the testing were: belching, postprandial fullness, nausea, bloating, and epigastric pain. None of the patients reported early satiety, heartburn, and vomiting during the testing. Most patients reported their symptoms in the interval between 5 minutes and 30 minutes during the testing, which coincides with the time when the antrum area in the group of patients with functional dyspepsia begins to differ significantly from the antrum area in the control group. There are no similar data in the literature.

The gastric emptying level at 120 minutes in relation to the most intense discomfort that occurred during the testing, was slowest in patients with nausea and postprandial fullness, which agrees with the data from the literature (15).

\section{CONCLUSION}

The patient who is suspected to have functional dyspepsia has to do numerous laboratory tests, imaging and endoscopic examinations but the diagnosis is mostly made upon the variety of subjective symptoms. It is known that the ultrasound measuring of the area of the antrum and change of its size in time is useful in assessing gastric functional disorders. We showed that the ultrasound measured antrum area in patients with functional dyspepsia, was statistically significantly larger starting from 30 minutes up to 120 minutes postprandially, which coincided with the appearance of symptoms. Also, the level of gastric emptying was significantly slower in patients with postprandial distress syndrome. Delayed gastric emptying was observed in subjects with nausea and postprandial fullness. Numerous methods for testing the function of the digestive tube are reserved for clinical studies and are not available in daily practice. Most of the methods are invasive, requiring expensive equipment and well-trained staff. Ultrasonography correlates well to other methods. It is reproducible, simple, available and non-invasive, and is therefore, the best option having in mind the patient's compliance. Ultrasonography has its disadvantages, it is a subjective method and gases in the stomach can significantly reduce visibility. Despite some limitations of ultrasonography, we suggest its use to be part of the diagnostic algorithm for the diagnosis of functional dyspepsia. 


\section{REFERENCES}

1. Drossman DA. Functional gastrointestinal disorders: history, pathophysiology, clinical features and Rome IV. Gastroenterology 2016; 150: 1262-1279.

2. Vincenzo S. Functional Dyspepsia and Irritable Bowel Syndrome: Beyond Rome IV. Dig Dis 2017; 35: 14-17.

3. Tack J, Bisschops R, Sarnelli G. Pathophysiology and treatment of functional dyspepsia. Gastroenterology 2004; 127: 1239-1255.

4. Timmons S, Liston R, Moriarty KJ. Functional dyspepsia: Motor abnormalities, sensory dysfunction, and therapeutic options. The American Journal of Gastroenterology 2004; 99: 739-749.

5. Lukasz D and Piotr J TH. Pathophysiological concepts of functional dyspepsia and irritable bowel syndrome future pharmacotherapy. Acta Poloniae Pharmaceutica 2006; 66 (5): 447-460.

6. Abell TL, Camilleri M, Donohoe K et al. Consensus recommendations for gastric emptying scintigraphy: a joint report of the American Neurogastroenterology and Motility Society and the Society of Nuclear Medicine. Journal of Nuclear Medicine Technology 2008; 36: 44-54

7. Mazzawi T, Bartsch E, Benammi S et all. Gastric Emptying of Low- and High-Caloric Liquid Meals Measured Using Ultrasonography in Healthy Volunteers. Ultrasound Int Open 2019; 5: 27-33.

8. Hveem K, Jones K L, Chatterton B E, Horowitz M. Scintigraphic measurement of gastric emptying and ultrasonographic assessment of antral area: relation to appetite. Gut 1996; 38: 816-821.

9. Bisschops R, Karamanolis G, Arts J, et al. Relationship between symptoms and ingestion of a meal in functional dyspepsia. Gut 2008; 57: 1495-1503.

10. Gassan D, Lars-Olof A, Ola B et al. Measurement of gastric emptying by standardized rel-time ultrasonography in healthy subjects and diabetic patients. J Ultrasound Med 1999; 18: 673-682.

11. Anahi P, Vincent W, Catalin M.et al. Ultrasound assessments of gastric content and volume. Anesthesiology 2009; 111:82-9
12. Stranghellini V, Tosetti C, Paternico A, Barbara G, et al. Risk indicators of delayed gastric emptying of solids in patients with functional dyspepsia. Gastroenterology 1996; 110: 1036-1042.

13. Sarnelli G, Caenapeei P, Geypens B, Janssens J, Tack J.Symptoms associated with impaired gastric emptying of solids and liquids in functional dyspepsia. Am J Gastroenterology 2003; 98: 783-788.

14. Hausken T, Berstad A. Wide gastric antrum in patients with non-ulcer dyspepsia. Effect of cisapride. Scandinavian Journal of Gastroenterology 1992; 27: 427-432

15. Gou W-J, Yao S-K, Zhang Y-L et al. Relationship between symptoms and gastric emptying of solids in functional dyspepsia. J International Medical Research 2012; 40:1725-1734.

16. Steinsvik EK, Hausken T, Gilja $\mathrm{OH}$. The ultrasound meal accommodation test in 509 patients with functional gastrointestinal disorders. Scandinavian Journal of Gastroenterology 2016; 51: 788-794

17. Szarka A L and Camilleri M. Methods for measurement of gastric motillity. Am J Phisiol Gastrointest Liver Physiol 2009; 296: 461475.

18. Odd H G, Trygve $\mathrm{H}$ et al. Gastric emptying measured by ultrasonography. WJG 1999; 5 (2): 93-94.

19. Tatyana Kugler The Usefulness of Water-drinking U1trasonography Combined Test for Evaluating Patients with Functional Dyspepsia. Korean J Gastroenterology 2015; 66 (2): 92-7.

20. Muhammad Hafeez et al. Gastric emptying scintigraphy in postprandial distress syndrome. Pak J Med Sci. 2018; 34 (1): $27-31$. 